\title{
ЭФФЕКТИВНЫЙ МЕТОД ИММОБИЛИЗАЦИИ ВЫСОКОАКТИВНЫХ ОТХОДОВ
}

\author{
Катаева О.И., Седнев Д.А. \\ Томский политехнический университет, 634050, г. Томск, пр. Ленина,30 \\ e-mail:o.i.kataeva@gmail.com
}

Вопрос обращения с радиоактивными отходами (РАО) сегодня актуален во многих странах. Это связанно с тем, что на многих АЭС в процессе эксплуатации скопилось большое количество РАО, кроме того в настоящие время многие станции в мире подлежат демонтажу. Сегодня технология остекловывания является одним из лучших способов утилизации высокоактивных отходов (ВАО). Применение данного метода значительно сокращает объем отходов, в результате чего образуется устойчивая к воздействию окружающей среды и пригодная для долговременного хранения форма РАО.

Из множества разработок выделяют две технологии процесса остекловывания, которые применяются в ядерной энергетике. Одна из них была разработан в Научно-исследовательском центре, Карлсруэ, Германия. Особенностью данной разработки является керамическая печь, плавление стекломассы в ней осуществляется за счет тепла, выделяющегося при прохождении электрического тока, подводимого к электродам непосредственно через расплав. Практика использования керамической печи в производстве обычного стекла показала, что возможно проводить плавление очень сложных по составу стекол и получать конечный продукт высокого качества. Кроме того керамические материалы обладают высокой жаропрочностью, превосходной коррозионной стойкостью и малой теплопроводностью, а также они являются хорошими диэлектриками.

В данной работе представлена схема иммобилизации отходов в стеклянную матрицу, рассмотрен принцип функционирования керамической печи. В экспериментальной части рассчитана зависимость удельного электрического сопротивления от температуры, измерения проводились в Научно-исследовательском центре, Германия, и по результатам эксперимента был выбран лучший тип керамики для плавильной печи.

*Выполнено при финансовой поддержки Благотворительного Фонда культурных инициатив (Фонд Михаила Прохорова).

1. G/ Roth, «INE's HLLW Vitrification Technology», atw 40. Jg., Heft 3, 1995, S. 144-177. 